\title{
Reflets
}

Revue ontaroise d'intervention sociale et communautaire

\section{Maison d'Amitié, une vidéo sur la violence psychologique}

Volume 3, numéro 1, printemps 1997

Enfance et familles en contexte d'appauvrissement

URI : https://id.erudit.org/iderudit/026163ar

DOI : https://doi.org/10.7202/026163ar

Aller au sommaire du numéro

Éditeur(s)

Reflets : Revue ontaroise d'intervention sociale et communautaire

ISSN

1203-4576 (imprimé)

1712-8498 (numérique)

Découvrir la revue

Citer ce compte rendu

(1997). Compte rendu de [Maison d'Amitié, une vidéo sur la violence psychologique]. Reflets, 3(1), 167-167. https://doi.org/10.7202/026163ar

Tous droits réservés (C) Reflets : Revue ontaroise d'intervention sociale et communautaire, 1997
Ce document est protégé par la loi sur le droit d'auteur. L'utilisation des services d'Érudit (y compris la reproduction) est assujettie à sa politique d'utilisation que vous pouvez consulter en ligne.

https://apropos.erudit.org/fr/usagers/politique-dutilisation/ 


\section{Maison d'Amitié, une vidéo sur la violence psychologique}

Cinq femmes de cultures et de milieux divers décrivent leur vie avant, pendant et après, leur séjour à la Maison d'Amitié, une maison d'hébergement pour femmes violentées. Leurs témoignages, entrecoupés de scènes de la vie de couple d'une simplicité éloquente, ont pour effet de démystifier tout autant la violence que la vie en maison d'hébergement où la chaleur et la solidarité que ces femmes découvrent leur redonnent foi en elles et en l'avenir.

Cette vidéo de $38 \mathrm{~min}$. $40 \mathrm{sec}$. est un document important sur la violence psychologique, un sujet délicat et peu exploité qu'ANGÈLE GAGNON aborde sans détour, avec beaucoup de doigté. C'est un document à voir absolument pour comprendre la subtilité des paroles et des gestes qui «désinventent» l'amour.

Les vidéocassettes sont disponibles pour un montant de $20 \$$ pour les particuliers, $75 \$$ pour les organismes sans but lucratif (avec possibilité de rabais selon la taille de l'organisme) et $150 \$$ pour les institutions.

Vous pouvez les commander en communiquant avec la Maison d'Amitié, 40 rue Cobourg, Ottawa (Ontario) K1N 8Z6. Renseignements : (613) 747-9136. 